\title{
The Effect of Multiple Micronutrient Supplementation on Mortality and Morbidity of HIV-Infected Adults: A Meta-Analysis of Randomized Controlled Trials
}

\author{
Shan JIANG, Juan HE, Xuejiao ZHAO and Hui LI* \\ Department of Biochemistry and Molecular Biology, Harbin Medical University, Harbin, China \\ (Received October 12, 2011)
}

\begin{abstract}
Summary Numerous preclinical studies have suggested that micronutrient status is associated with the progression of human immunodeficiency virus (HIV) disease, but results from observational studies are still controversial. The objective was to systematically review the efficacy of multiple micronutrient supplementation on mortality and morbidity in HIVinfected adults. A comprehensive search of the PubMed/MEDLINE, EMBASE and Cochrane Library was performed. Six randomized controlled trials assessing the effect of multiple micronutrient supplementation on HIV-infected adults were included. Relative risk was used as an effect measure to compare the intervention and control groups with fixed-effects or random effects models. Sensitivity analyses were applied to further evaluate heterogeneity. Multiple micronutrient supplementation decreased the mortality and morbidity of HIVinfected adults nonstatistically significantly ( $\mathrm{RR}=0.90 ; 95 \% \mathrm{CI}, 0.80$ to $1.02 ; p=0.09$ ). Sensitivity analyses revealed that multiple micronutrient supplementation decreased the mortality and morbidity of adults infected with HIV alone statistically significantly $(\mathrm{RR}=0.75 ; 95 \% \mathrm{CI}, 0.58$ to $0.95 ; p=0.02)$, but not adults infected with both HIV and pulmonary tuberculosis $(\mathrm{RR}=0.97 ; 95 \% \mathrm{CI}, 0.84$ to $1.11 ; p=0.65)$. Multiple micronutrient consumption was correlated with reduction of the mortality and morbidity of HIV-infected adults, at least those in developing countries and infected with HIV alone, and should be prescribed by local doctors for those in earlier stages especially.
\end{abstract}

Key Words multiple micronutrient supplementation, mortality, HIV, meta-analysis, Randomized controlled trial

It is estimated that 33 million people worldwide are infected with human immunodeficiency virus (HIV), many of whom have symptoms of the acquired immunodeficiency syndrome (AIDS). From its discovery in 1981 to 2006, AIDS killed more than 25 million people. Over $95 \%$ of the global total of AIDS cases are in the developing world, especially in sub-Saharan Africa, with prevalence among adults at more than $10 \%$ in several African countries. The "Treat 3 million by 2005" plan of World Health Organization (WHO) demonstrated that patients with advanced disease will receive antiretroviral treatment, while those in earlier stages will be monitored and given supportive care (1). It is therefore reasonable and cost-effective to find some inexpensive ways to retard the progression to AIDS and death of HIV-infected patients.

When referring to the mechanisms of progression to AIDS, previous preclinical studies have revealed that oxidative stress may play an important role in the stimulation of HIV replication, the reduction in the number of circulating $\mathrm{T}$ lymphocytes and the development of immunodeficiency $(2,3)$. Antioxidant micronutrients, cheap and easily tolerated agents, have been revealed to

*To whom correspondence should be addressed.

E-mail: lihui@ems.hrbhmu.edu.cn be correlated to not only antioxidant function but also the enhancement of immunity, and several observational studies have reported that a lot of micronutrient deficiencies among HIV-infected patients are associated strongly with the progression to AIDS and death (4-6).

Previous meta-analyses have demonstrated that micronutrient supplementation may be associated with reduction of mortality and morbidity among oxidativeinjury related diseases, such as cardiovascular disease and cancer (7-9), but meta-studies on its relationship with infectious diseases are still scarce. Thus, we conducted a meta-analysis of randomized controlled trials to further illuminate whether multiple micronutrient supplementation was effective in reducing mortality and morbidity among HIV-infected adults.

\section{METHODS}

Search strategy and study assessment. PubMed/MEDLINE (September 2011), EMBASE (September 2011), and Cochrane Library (issue 9 2011) were searched for all randomized controlled trials (RCTs) on micronutrient supplementation and HIV-infected adults. The following Medical Subject Heading (MeSH) items and freetext words were variously combined to identify all RCTs as far as possible: micronutrient, multiple micronutrient, antioxidant, HIV, AIDS, mortality, morbidity, clini- 


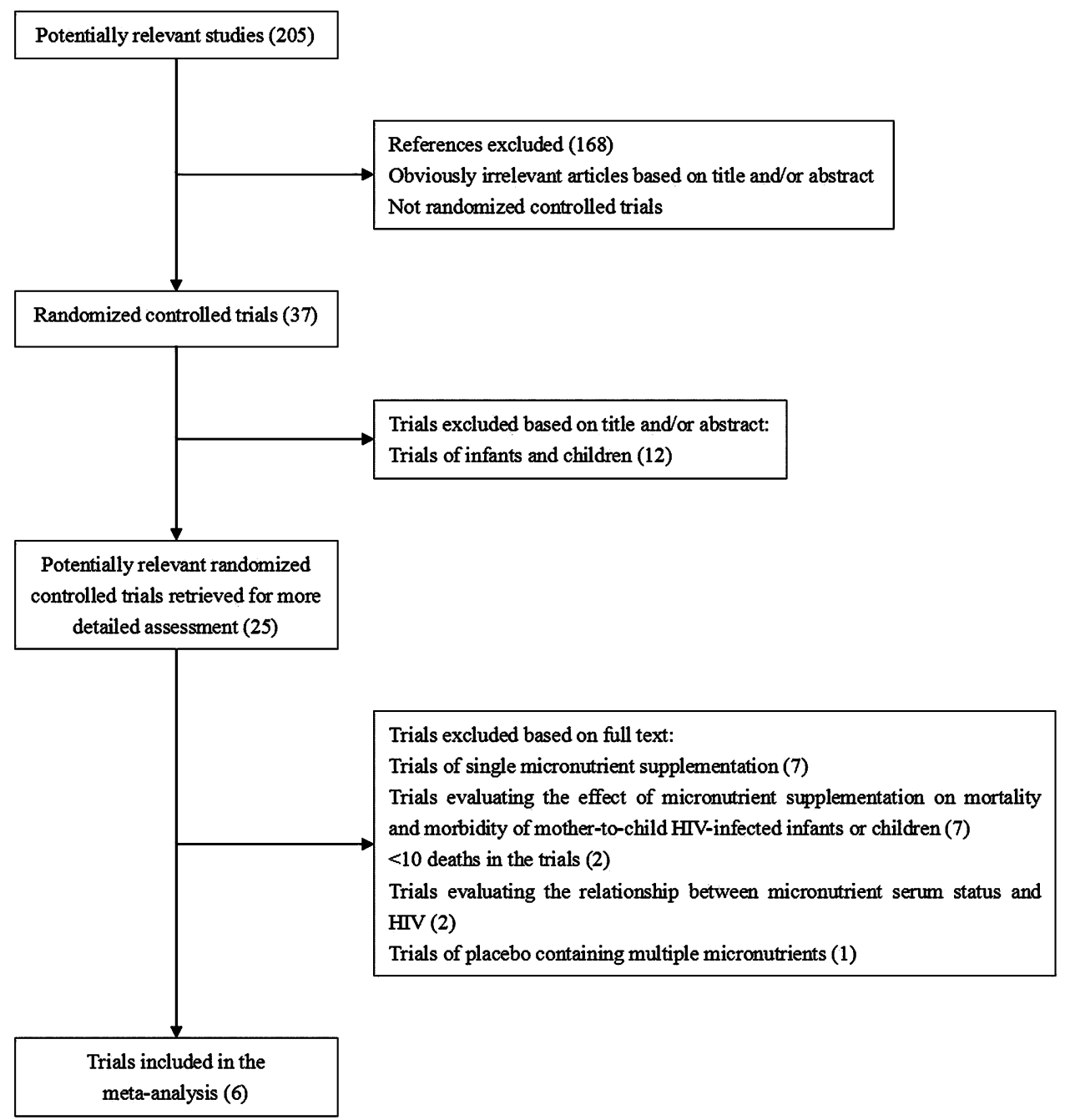

Fig. 1. Flowchart of trial selection.

cal trial, randomized controlled trial, controlled clinical trial, and placebo controlled trial. Reference lists of relevant review articles were reviewed, and RCTs meeting the inclusion criteria discussed below were recruited in our meta-analysis. Two investigators (S. Jiang and J. He) independently manipulated the electronic search and assessed the title and abstract of every retrieved RCT, and if necessary, full articles were retrieved for further assessment to determine articles which met the inclusion criteria. The frequently used Jadad scale for assessing quality and risk of bias of RCTs has been discouraged by the Cochrane Collaboration; therefore, the same two investigators evaluated the quality of these studies applying the Jadad criteria. Only studies with a Jadad score of 3 or higher were included in our review. Discrepancies were resolved by consulting the third investigator (X. Zhao).

Study selection criteria. The titles and abstracts of all articles identified by the search strategy were retrieved for further review. Inclusion criteria were then applied to all potentially relevant RCTs. The inclusion criteria for the meta-analysis were as follows: (1) only RCTs evaluating the efficacy of multiple micronutrients on mortality and morbidity of HIV-infected adults; (2) study samples limited to adults infected with HIV; (3) trials with double-blinding and placebo-control.

Data extraction. Two investigators (X. Zhao and H. Li) extracted the data of all included trials using a standardized protocol. Data extracted were as follows: (1) number of participants enrolled in each trial; (2) number of participants in intervention and control arms; (3) population of participants in each trial; (4) mean age of participants; (5) types and dosages of micronutrient intake; (6) concomitant diseases in each trial; (7) follow-up year; (8) dropout numbers in each trial; (9) publication year.

Statistical analyses. All statistical analyses but Begg's rank correlation test were performed using Review Manager 5.0 software programs (Cochrane Collaboration) for the performance of meta-analysis. Dichotomous data were expressed as relative risk (RR) with $95 \%$ confidence intervals $(95 \% \mathrm{CI})$. In pooling the data from these included trials, a fixed-effects model was applied using the method of Mantel-Haenzel (M-H) when there was no statistically significant heterogeneity. A random effects model was employed using the method of DerSimonian and Laird (DL) if statistically significant heterogeneity was detected. The $\chi^{2}$ test was employed to assess whether or not any clinical, methodological, or statistical heterogeneity existed among 
Table 1. Characteristics of included trials.

\begin{tabular}{|c|c|c|c|c|c|}
\hline $\begin{array}{l}\text { Study, year } \\
\text { (reference) }\end{array}$ & Country & Participants & Mean age, y & Micronutrients & Follow-up, y \\
\hline
\end{tabular}

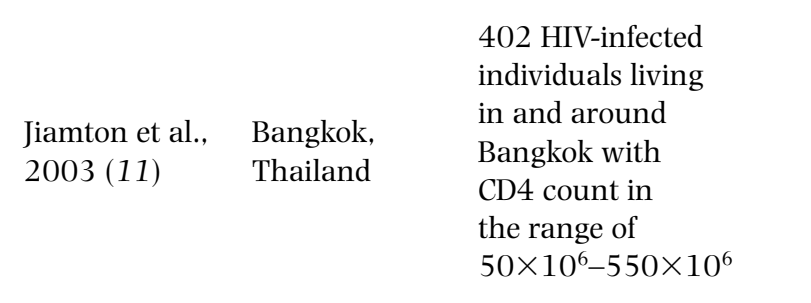

\begin{tabular}{lll}
\hline Fawzi et al., & Dar es Salaam, \\
2004 (12) & Tanzania & $\begin{array}{l}806 \text { pregnant } \\
\text { women infected } \\
\text { with HIV }\end{array}$
\end{tabular}

181 HIV-positive patients aged

Range et al., Mwanza, 2006 (13) Tanzania vitamin A 3,000 $\mu \mathrm{g}$, betacarotene $6 \mathrm{mg}$, vitamin D $20 \mu \mathrm{g}$, vitamin E $80 \mathrm{mg}$, vitamin $\mathrm{K} 180 \mu \mathrm{g}$, vitamin C $400 \mathrm{mg}$, vitamin $\mathrm{B}_{1}$ $24 \mathrm{mg}$, vitamin $\mathrm{B}_{2} 15 \mathrm{mg}$, vitamin $\mathrm{B}_{6}$ 32 $40 \mathrm{mg}$, vitamin $\mathrm{B}_{12} 30 \mu \mathrm{g}$, folacin $100 \mu \mathrm{g}$, panthothenic acid $40 \mathrm{mg}$, iron $10 \mathrm{mg}$, magnesium $200 \mathrm{mg}$, manganese $8 \mathrm{mg}$, zinc $30 \mathrm{mg}$, iodine $300 \mu \mathrm{g}$, copper $3 \mathrm{mg}$, selenium $400 \mu \mathrm{g}$, chromium $150 \mu \mathrm{g}$, and cystine $66 \mathrm{mg}$

$20 \mathrm{mg}$ of vitamin $\mathrm{B}_{1}, 20 \mathrm{mg}$ of vitamin $\mathrm{B}_{2}$, $2525 \mathrm{mg}$ of vitamin $\mathrm{B}_{6}, 100 \mathrm{mg}$ of niacin, 5.9 $30 \mathrm{mg}$ of vitamin $\mathrm{E}$, and $0.8 \mathrm{mg}$ of folic acid

\begin{tabular}{|c|c|c|c|c|c|}
\hline $\begin{array}{l}\text { Range et al., } \\
2006(13)\end{array}$ & $\begin{array}{l}\text { Mwanza, } \\
\text { Tanzania }\end{array}$ & $\begin{array}{l}181 \text { HIV-positive } \\
\text { patients aged } \\
\geq 15 \text { y with } \\
\text { sputum-positive } \\
\text { pulmonary } \\
\text { tuberculosis }\end{array}$ & 35 & $\begin{array}{l}\text { Vitamin A } 1.5 \mathrm{mg} \text {, vitamin } B_{1} 20 \mathrm{mg} \text {, } \\
\text { vitamin } B_{2} 20 \mathrm{mg} \text {, vitamin } B_{6} 25 \mathrm{mg}, \\
\text { vitamin } B_{12} 50 \mathrm{mg} \text {, folic acid } 0.8 \mathrm{mg} \text {, } \\
\text { niacin } 40 \mathrm{mg} \text {, vitamin C } 200 \mathrm{mg} \text {, vitamin E } \\
60 \mathrm{mg} \text {, vitamin } \mathrm{D}_{3} 5 \mathrm{mg} \text {, selenium } 0.2 \mathrm{mg} \text {, } \\
\text { copper } 5 \mathrm{mg} \text {, and } \mathrm{Zn} 45 \mathrm{mg}\end{array}$ & 0.67 \\
\hline
\end{tabular}

\begin{tabular}{|c|c|c|c|c|c|}
\hline $\begin{array}{l}\text { Semba et al., } \\
2007(14)\end{array}$ & $\begin{array}{l}\text { Zomba and } \\
\text { Blantyre, } \\
\text { Malawi }\end{array}$ & $\begin{array}{l}328 \text { HIV-positive } \\
\text { patients with } \\
\text { pulmonary } \\
\text { tuberculosis }\end{array}$ & $\begin{array}{l}\text { micronutrients } \\
\text { group: } 34 \\
\text { placebo group: } \\
33.1\end{array}$ & $\begin{array}{l}\text { vitamin A } 2.4 \mathrm{mg} \text {, vitamin C } 500 \mathrm{mg} \text {, } \\
\text { vitamin } \mathrm{D} 10 \mu \mathrm{g} \text {, vitamin E } 181.8 \mathrm{mg} \text {, } \\
\text { vitamin } \mathrm{B}_{6} 2 \mathrm{mg} \text {, vitamin } \mathrm{B}_{12} 6 \mu \mathrm{g} \text {, } \\
\text { riboflavin } 1.7 \mathrm{mg} \text {, thiamin } 1.5 \mathrm{mg} \text {, niacin } \\
20 \mathrm{mg} \text {, folate } 0.4 \mathrm{mg} \text {, zinc } 10 \mathrm{mg} \text {, iodine } \\
175 \mu \mathrm{g} \text {, and selenium } 65 \mu \mathrm{g}\end{array}$ & 1.04 \\
\hline
\end{tabular}

$\beta$-carotene $4.8 \mathrm{mg}$, vitamin C $70 \mathrm{mg}$, vitamin D $5 \mu \mathrm{g}$, vitamin $\mathrm{E} 10 \mathrm{mg}$, vitamin

\begin{tabular}{|c|c|c|c|c|}
\hline $\begin{array}{l}\text { Kelly et al., } \\
2008 \text { (15) }\end{array}$ & $\begin{array}{l}\text { Misisi, Lusaka, } \\
\text { Zambia }\end{array}$ & $\begin{array}{l}136 \text { individuals } \\
\text { infected with } \\
\text { HIV }\end{array}$ & 34 & $\begin{array}{l}\mathrm{B}_{1} 1.4 \mathrm{mg} \text {, vitamin } \mathrm{B}_{2} 1.4 \mathrm{mg} \text {, niacin } \\
18 \mathrm{mg} \text {, vitamin } \mathrm{B}_{6} 1.9 \mathrm{mg} \text {, vitamin } \mathrm{B}_{12} \\
2.6 \mu \mathrm{g} \text {, folic acid } 400 \mu \mathrm{g} \text {, iron } 30 \mathrm{mg} \text {, zinc } \\
15 \mathrm{mg} \text {, copper } 2 \mathrm{mg} \text {, selenium } 65 \mu \mathrm{g} \text {, and } \\
\text { iodine } 150 \mu \mathrm{g}\end{array}$ \\
\hline
\end{tabular}

$5,000 \mathrm{IU}$ of retinol, $20 \mathrm{mg}$ of vitamin $\mathrm{B}_{1}$,

471 individuals

Villamor et al., Dar es Salaam, infected with HIV 2008 (16) Tanzania and pulmonary tuberculosis $20 \mathrm{mg}$ of vitamin $\mathrm{B}_{2}, 25 \mathrm{mg}$ of vitamin $\mathrm{B}_{6}$, $100 \mathrm{mg}$ of niacin, $50 \mu \mathrm{g}$ of vitamin $\mathrm{B}_{12}$, $500 \mathrm{mg}$ of vitamin C, $200 \mathrm{mg}$ of vitamin E, $0.8 \mathrm{mg}$ of folic acid, and $100 \mu \mathrm{g}$ of selenium these included trials. Statistical significance of the test for heterogeneity was set at 0.05. Sensitivity analysis was applied to further evaluate the heterogeneity. The potential publication bias in the meta-analysis was examined by checking the relationship between the intervention effects and the standard error of the estimate by applying a funnel plot visually. Begg's rank correlation test was conducted using Stata version 11.0 to evaluate the publication bias quantificationally.

\section{RESULTS}

\section{Literature search}

The detailed search step was summarized in a flow- chart illustrating the process of exclusion for certain studies according to the Quality of Reporting of Metaanalysis (QUOROM) recommendations (10) (Fig. 1). We initially identified 205 potentially relevant articles. One hundred sixty-eight references were excluded because of study design based on titles and/or abstracts, and then 37 HIV-related RCTs were retained for further assessment. Of all these RCTs, 7 trials with single micronutrient supplementation, 7 trials evaluating the effect of micronutrient supplementation on mortality and morbidity of mother-to-child HIV-infected infants or children, 2 trials with fewer than 10 deaths, 2 trials evaluating the relationship between micronutrient 
Table 2. Quality assessment of included trials.

\begin{tabular}{|c|c|c|c|c|c|}
\hline Study, year & Randomization & Blinding & Placebo-controlled & Dropout $(n)$ & Jadad score \\
\hline Jiamton et al., 2003 & adequate & double-blind & yes & 79 & 5 \\
\hline Fawzi et al., 2004 & unclear & double-blind & yes & 0 & 4 \\
\hline Range et al., 2006 & adequate & double-blind & yes & not stated & 3 \\
\hline Semba et al., 2007 & adequate & double-blind & yes & 103 & 5 \\
\hline Kelly et al., 2008 & adequate & double-blind & yes & not stated & 4 \\
\hline Villamor et al., 2008 & adequate & double-blind & yes & 0 & 5 \\
\hline
\end{tabular}

Adequate, if the allocation sequence was generated by a computer or random number table. Unclear, if the trial was described as randomized, but the method used for the allocation sequence generation was not described.

\begin{tabular}{|c|c|c|c|c|c|c|}
\hline Study, year & $\begin{array}{c}\text { Multiple micr } \\
\text { Events }\end{array}$ & $\begin{array}{l}\text { ronutrients } \\
\text { Total }\end{array}$ & $\begin{array}{c}\text { Control } \\
\text { Events Total }\end{array}$ & $\begin{array}{c}\text { Relative Risk } \\
\text { M-H, Fixed, } 95 \% \text { CI }\end{array}$ & $\begin{array}{c}\text { Weight } \\
\%\end{array}$ & $\begin{array}{c}\text { Relative Risk } \\
\text { M-H, Fixed, 95\% CI }\end{array}$ \\
\hline $\begin{array}{l}\text { Jiamton etal, } 2003 \\
\text { Fawzi etal, } 2004 \\
\text { Range etal, } 2006 \\
\text { semba etal, } 2007 \\
\text { Kelly etal, } 2008 \\
\text { Villamor etal, } 2008\end{array}$ & $\begin{array}{r}8 \\
112 \\
15 \\
157 \\
4 \\
74\end{array}$ & $\begin{array}{r}242 \\
539 \\
87 \\
406 \\
69 \\
233\end{array}$ & $\begin{array}{rr}15 & 239 \\
66 & 267 \\
27 & 94 \\
171 & 423 \\
12 & 67 \\
66 & 238\end{array}$ & $+\frac{1}{2}$ & $\begin{array}{r}4.03 \\
23.58 \\
6.93 \\
44.75 \\
3.25 \\
17.45\end{array}$ & $\begin{array}{l}0.53[0.23,1.22] \\
0.84[0.64,1.10] \\
0.60[0.34,1.05] \\
0.96[0.81,1.13] \\
0.32[0.11,0.95] \\
1.15[0.87,1.51]\end{array}$ \\
\hline $\begin{array}{l}\text { Total (95\% CI) } \\
\text { Test for heterogene } \\
\text { Test for overall effec }\end{array}$ & $\begin{array}{l}\text { hile }=10.66, \mathrm{df} \\
=1.70(P=0 .\end{array}$ & $\begin{array}{l}1576 \\
=5(P=0.0 \\
09)\end{array}$ & $t 2=53.1 \%$ & & 100.00 & $0.90[0.80,1.02]$ \\
\hline
\end{tabular}

Fig. 2. Efficacy on mortality and morbidity of HIV-infected adults. CI, confidence interval.

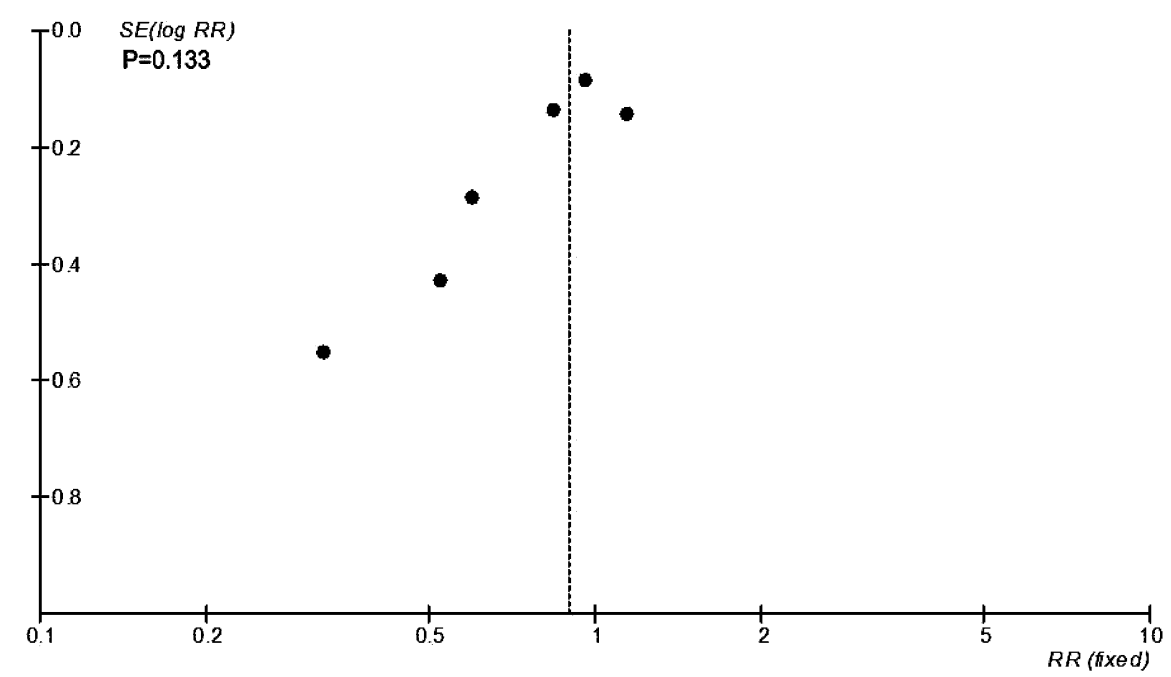

Fig. 3. Funnel plot for the publication bias of all 6 included trials. $p$-value is derived from Begg's rank correlation test.

serum status and HIV and 1 trial with a placebo containing multiple micronutrients were also excluded. At last, we included 6 RCTs in the meta-analysis (11-16) (Table 1).

Description of included RCTs

The quality of included studies is shown in Table 2 . All trials were randomized, double-blinded and placebocontrolled, and received Jadad scores of $3(n=1), 4$ $(n=2)$, or $5(n=3)$ points. All but one trial reported nonstatistically significant reduction or increase in mortality and morbidity of HIV-infected adults. The included trials were reported between 2003 and 2008, and their sample sizes varied between 136 and 806 participants. The numbers of micronutrient types ranged from 8 to 21 , and 7 kinds of micronutrients, namely vitamin $\mathrm{B} 1$, vitamin $\mathrm{B} 2$, vitamin B6, vitamin $\mathrm{B} 12$, vitamin $\mathrm{C}$, vitamin $\mathrm{E}$ and folic acid, were common to the 6 included trials. The dosages used in these supplements were about six to ten times higher than the recommended daily allowances (RDA) (17) for healthy individuals in 4 of the 6 trials $(11-13,16)$, and the other 2 trials administered the dosages approximately equal to RDA except for the higher dosages of vitamin A, $\mathrm{C}$ and $\mathrm{E}$ in 1 of the 2 trials $(14,15)$. All of these supplements were prescribed daily. The mean ages of included trials ranged from 25 to 35 , and the average 


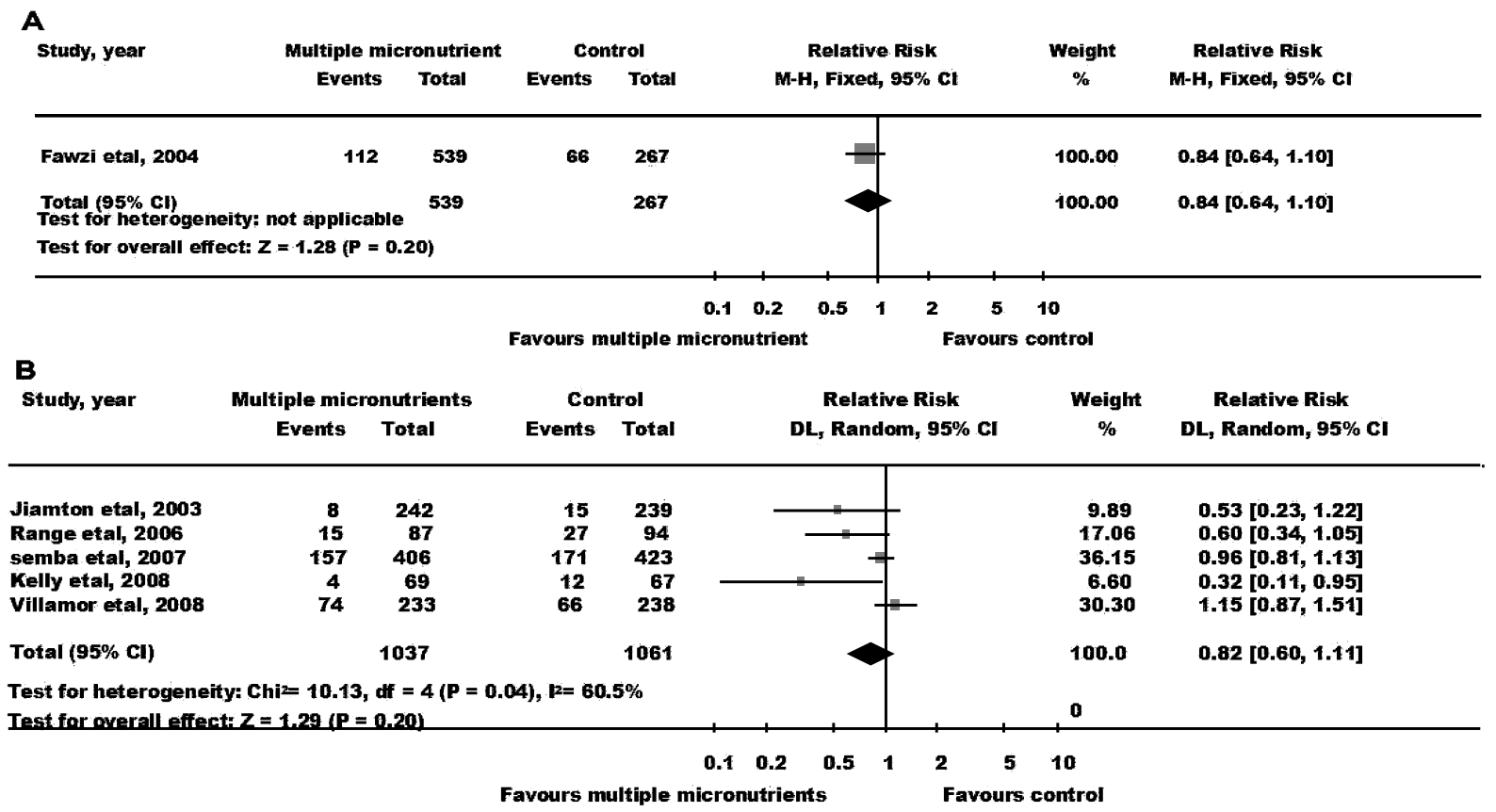

Fig. 4. Efficacy on mortality and morbidity of pregnant women (A) and non-pregnant adults (B). CI, confidence interval.

A

\begin{tabular}{|c|c|c|c|c|c|c|c|}
\hline \multirow[t]{2}{*}{ Study, year } & \multicolumn{2}{|c|}{ multiple micronutrient } & \multicolumn{2}{|c|}{ Control } & \multirow{2}{*}{$\begin{array}{c}\text { Relative Risk } \\
\text { M-H, Fixed, } 95 \% \text { CI }\end{array}$} & \multirow{2}{*}{$\begin{array}{c}\text { Weight } \\
\%\end{array}$} & \multirow{2}{*}{$\begin{array}{c}\text { Relative Risk } \\
\text { M-H, Fixed, } 95 \% \text { CI }\end{array}$} \\
\hline & Events & Total & Events & Total & & & \\
\hline $\begin{array}{l}\text { Fawzi etal, } 2004 \\
\text { Jiamton etal, } 2003 \\
\text { Kelly etal, } 2008\end{array}$ & $\begin{array}{r}112 \\
8 \\
4\end{array}$ & $\begin{array}{c}539 \\
201 \\
69\end{array}$ & $\begin{array}{c}66 \\
15 \\
12\end{array}$ & $\begin{array}{c}267 \\
201 \\
67\end{array}$ & 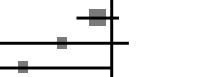 & $\begin{array}{l}76.46 \\
12.99 \\
10.55\end{array}$ & $\begin{array}{l}0.84[0.64,1.10] \\
0.53[0.23,1.23] \\
0.32[0.11,0.99]\end{array}$ \\
\hline $\begin{array}{l}\text { Total }(95 \% \mathrm{Cl}) \\
\text { Test for heterogene } \\
\text { Test for overall effer }\end{array}$ & $\begin{array}{l}\text { : Chiz= } 3.68 \\
Z=2.33(P\end{array}$ & $\begin{array}{l}809 \\
d f=2(P= \\
0.02)\end{array}$ & $12=45$ & 535 & & 100.00 & $0.75[0.58,0.95]$ \\
\hline
\end{tabular}

Test for overall effect: $Z=2.33(P=0.02)$

$\begin{array}{lllllll}0.1 & 0.2 & 0.5 & 1 & 2 & 5 & 10\end{array}$

$\mathbf{B}$

Favours multiple micronutrient Favours control

\begin{tabular}{|c|c|c|c|c|c|c|c|}
\hline \multirow[t]{2}{*}{ Study, year } & \multicolumn{2}{|c|}{ Multiple micronutrients } & \multicolumn{2}{|c|}{ Control } & \multirow{2}{*}{$\begin{array}{l}\text { Relative Risk } \\
\text { M-H, Fixed, } 95 \% \text { Cl }\end{array}$} & \multirow{2}{*}{$\begin{array}{l}\text { Weight } \\
\%\end{array}$} & \multirow{2}{*}{$\begin{array}{l}\text { Relative Risk } \\
\text { M-H, Fixed, } 95 \% \text { Cl }\end{array}$} \\
\hline & Events & Total & Events & Total & & & \\
\hline $\begin{array}{l}\text { Range etal, } 2006 \\
\text { semba etal, } 2007 \\
\text { Villamor etal, } 2008\end{array}$ & $\begin{array}{r}15 \\
157 \\
74\end{array}$ & $\begin{array}{r}87 \\
406 \\
233\end{array}$ & $\begin{array}{r}27 \\
171 \\
66\end{array}$ & $\begin{array}{r}94 \\
423 \\
238\end{array}$ & & $\begin{array}{l}10.03 \\
64.73 \\
25.24\end{array}$ & $\begin{array}{l}0.60[0.34,1.05] \\
0.96[0.81,1.13] \\
1.15[0.87,1.51]\end{array}$ \\
\hline Total (95\% Cl) & & 726 & & 755 & & 100.00 & $0.97[0.84,1.11]$ \\
\hline \multicolumn{8}{|c|}{$\begin{array}{l}\text { Test for heterogeneity: Chi } 2=4.22, \mathrm{df}=2(P=0.12), \mid=52.6 \% \\
\text { Test for overall effect: } Z=0.45(P=0.65)\end{array}$} \\
\hline
\end{tabular}

Fig. 5. Efficacy on mortality and morbidity of adults infected with HIV alone (A) and infected with HIV and pulmonary tuberculosis (B). CI, confidence interval.

follow-up years ranged from 0.67 to $5.9 \mathrm{y}$. Participants in 3 trials were infected with pulmonary tuberculosis concomitantly.

Effect of multiple micronutrient supplementation on mortality and morbidity in HIV-infected adults

Overall, multiple micronutrient supplementation nonstatistically significantly decreased the mortality and morbidity of HIV-infected adults. The pooled relative risk (RR) comparing intervention with control groups was 0.90 (95\% CI, 0.80 to $1.02 ; p=0.09)$ when applying the fixed-effects model (Fig. 2). The funnel plot showed an asymmetric pattern, but Begg's rank correlation test suggested no publication bias in the metaanalysis ( $p=0.133)$ (Fig. 3).

Sensitivity analysis

Firstly, these included trials were divided into trials of pregnant women and trials of non-pregnant adults. The pooled RR of pregnant women was 0.80 (95\% CI, 0.56 to $1.13 ; p=0.20)$, and the pooled RR of non-pregnant adults was 0.75 (95\% CI, 0.50 to $1.12 ; p=0.16$ ) (Fig. 4). they provided similar estimations of the RR, which indicated that the pregnant condition did not alter the 
effect of multiple micronutrient supplementation.

Then we disaggregated these included trials into trials of participants infected with HIV alone and infected with pulmonary tuberculosis concomitantly. The pooled RR of those infected with HIV alone was 0.75 (95\% CI, 0.58 to $0.95 ; p=0.02$ ), and the pooled RR of trials of participants infected with pulmonary tuberculosis concomitantly was 0.97 (95\% CI, 0.84 to 1.11 ; $p=0.65)$ (Fig. 5).

\section{DISCUSSION}

Many previous and ongoing preclinical studies have demonstrated that micronutrient supplementation can enhance the immune function and decrease oxidative damage, and thus can retard or inhibit the progression of some infectious and oxidative injury-related diseases (18-21). When evaluating in an epidemic view, however, the effects of micronutrient supplementation on immune function and oxidative damage were disappointing, and even conflicting (22-24). One plausible explanation is the limitation of sample size in some observational studies. AIDS, which progressed from HIV infection, was characterized by the dysfunction of the immune system - a reduction in the $\mathrm{CD} 4+$ cell count. In recent two decades, oxidative stress was reported to be correlated with a faster progression of AIDS (25-27). Thus, clinical trials evaluating the effect of micronutrient supplementation on prognosis of HIV infection and AIDS were enforced extensively in recent years.

This is a meta-analysis to evaluate the efficacy of multiple micronutrient supplementation on the mortality and morbidity of HIV-infected adults. Our assessment was based on six included RCTs that were published within the past $10 \mathrm{y}$. The results of the metaanalysis revealed that adults infected with HIV could benefit from multiple micronutrient supplementation, which could decrease the mortality and morbidity, especially those infected with HIV alone. Wasting, which is characterized by an involuntary, progressive loss of lean and fat mass, is one of the strongest independent predictors of mortality in HIV-infected adults according to the results of studies carried out in developing and developed countries (28-30). The oral and gastrointestinal manifestations, nausea, vomiting and diarrhea, which are largely correlated with wasting and are more likely to be observed in advanced stages of HIV disease could influence the appetite and nutrition absorption of patients in addition to decreasing their quality of life (31). Many previous studies have revealed that supplementation of micronutrients could maintain the integrity of oral and gastrointestinal epithelia and thus decrease episodes of oral and gastrointestinal symptoms to improve local and systemic immunity $(32,33)$. Consequently, multimicronutrient supplementation may prolong survival time through reducing the incidence of wasting and favorably affect the prognosis of AIDS patients.

The results of sensitivity analysis revealed that although both patients infected with and without tuberculosis were supplemented with multiple micronutrients, only those who are infected with HIV alone can benefit from multiple micronutrient supplementation with a favorably decreased and stastistically significant RR of 0.75. Those who are infected concomitantly with tuberculosis cannot benefit from multiple intake of micronutrients with a RR approximately equal to 1 , indicating that these patients may have progressed to a more severe situation of immune dysfunction and oxidative stress injury which can not be reversed by multimicronutrient consumption. This result was in accordance with a previous observational study which assessed the differences of clinical symptom incidences between AIDS patients infected and uninfected with tuberculosis (34). It demonstrated that AIDS patients infected with tuberculosis were more likely to develop fever, weight loss and lymphadenopathy. As has been discussed in the previous paragraph, similar to wasting, weight loss may be attributed to oral and gastrointestinal symptoms. The influence of fever and oxidative stress may be reciprocal. Riedel and Maulik revealed that fever is an integrated response of the central nervous system to oxidative stress (35), and several other studies indicated that fever can increase the lipid peroxidation parameters, decrease the cell antioxidant system (36) and induce oxidative stress (37). Lymphadenopathy was reported to be correlated with immune dysfunction (38). All this evidence supported our conjecture that patients infected with both HIV and tuberculosis may have progressed to a more severe situation of immune dysfunction and oxidative stress when compared with those infected with HIV alone. Nevertheless, the probable decreasing effect of multiple micronutrient supplementation on mortality and morbidity of total HIV-infected patients cannot be ruled out (Fig. 2).

Intervention of the meta-analysis was restricted within multiple micronutrient supplementation. Previous preclinical studies have revealed that multiple intake of micronutrients can improve their respective roles in strengthening immune system function and antioxidation reciprocally. For example, the antioxidant efficacy of vitamin $\mathrm{E}$ can be strengthened by vitamin $\mathrm{C}$ (39), $\beta$-carotene and selenium $(40,41)$, and vitamin $\mathrm{E}$ can play an analogous biochemical role to that of zinc in stablizing membrane structure and reducing peroxidative damage (42). In several observational studies assessing the efficacy of only one or two kinds of micronutrients on progression of HIV infection, the results are even opposite $(43,44)$. One of the included RCTs evaluating the efficacy of both multivitamins and vitamin A revealed that multivitamin supplementation can significantly delay the progression of HIV-infection; however, supplementation with vitamin A alone had weaker effects that for the most part were not significantly different from those produced by the placebo (12). We all know fruits and vegetables are rich in multiple micronutrients, and Winkler et al. reported that HIV-infected patients can benefit from supplementation with fruit juices (45). Therefore, the cooperative interactions among these micronutrients may play a partial 
role in the reduction of the mortality and morbidity of HIV-infected patients, and more meta-analyses assessing the effect of a single micronutrient should be carried out in the future.

There is a weakness which may limit the generalizability of the meta-analysis. All of the six included trials were carried out in developing countries, four of which were in sub-Saharan Africa. Trials in Europe, America and Oceania could not be found through our search strategy. Most of the advanced countries are on these three continents. Moreover, micronutrient deficiencies are more likely to happen in residents of developing countries, especially in sub-Saharan Africa, but not in developed countries. Thus, the effect of multiple micronutrient supplementation on residents of advanced countries should be considered cautiously, and there is a need for more double-blinded RCTs from these countries. Another limitation was the different formulations and dosages of micronutrients in the six trials, which might be inevitable in meta-analysis, an analytical approach based on published literature. Anyhow, all of the intaken micronutrients in each trial were included in the recommended daily allowance, and the strengthened effects among them cannot be ruled out. Only trials published in English were included, so there might also be a language bias.

In conclusion, our study demonstrates that multiple micronutrient consumption can decrease the mortality and morbidity of HIV-infected patients, at least those in developing countries. Based on the synthesized treatment methods of the 6 included RCTs, we suggest that multiple micronutrients, including the 7 types of common micronutrients (vitamin B group, vitamin C, vitamin $\mathrm{E}$ and folic acid) and several frequently prescribed ones (vitamin A, vitamin D, zinc, selenium and niacin), should be administered daily between the equivalent dosages of RDA and six to ten times the dosages of RDA, depending on the varying stages of AIDS, by local doctors. In the future, recently completed and other ongoing trials will provide more precise answers on the relationship between multimicronutrient intake and prognosis of HIV infection.

\section{Acknowledgments}

This study was funded by the Natural Science Foundation of China (No. 30771863 and No. 81172616), and not funded by any pharmaceutical company.

\section{REFERENCES}

1) Initiative TMb. 2003. Treating 3 Million by 2005: Making It Happen: the WHO Strategy. World Health Organization, Geneva.

2) Wong GH, McHugh T, Weber R, Goeddel DV. 1991. Tumor necrosis factor alpha selectively sensitizes human immunodeficiency virus-infected cells to heat and radiation. Proc Natl Acad Sci USA 88: 4372-4376.

3) Schreck R, Rieber P, Baeuerle PA. 1991. Reactive oxygen intermediates as apparently widely used messengers in the activation of the NF-kappa B transcription factor and HIV-1. EMBO J 10: 2247-2258.

4) Tang AM, Graham NM, Saah AJ. 1996. Effects of micro- nutrient intake on survival in human immunodeficiency virus type 1 infection. Am J Epidemiol 143: 1244-1256.

5) Baum MK, Shor-Posner G, Lai S, Zhang G, Lai H, Fletcher MA, Sauberlich H, Page JB. 1997. High risk of HIV-related mortality is associated with selenium deficiency. J Acquir Immune Defic Syndr Hum Retrovirol 15: 370-374.

6) Semba RD, Tang AM. 1999. Micronutrients and the pathogenesis of human immunodeficiency virus infection. Br J Nutr 81: 181-189.

7) Bardia A, Tleyjeh IM, Cerhan JR, Sood AK, Limburg PJ, Erwin PJ, Montori VM. 2008. Efficacy of antioxidant supplementation in reducing primary cancer incidence and mortality: systematic review and meta-analysis. Mayo Clin Proc 83: 23-34.

8) Shekelle PG, Morton SC, Jungvig LK, Udani J, Spar M, Tu W, Suttorp MJ, Coulter I, Newberry SJ, Hardy M. 2004. Effect of supplemental vitamin E for the prevention and treatment of cardiovascular disease. J Gen Intern Med 19: 380-389.

9) Flores-Mateo G, Navas-Acien A, Pastor-Barriuso R, Guallar E. 2006. Selenium and coronary heart disease: a meta-analysis. Am J Clin Nutr 84: 762-773.

10) Moher D, Cook DJ, Eastwood S, Olkin I, Rennie D, Stroup DF. 1999. Improving the quality of reports of metaanalyses of randomised controlled trials: the QUOROM statement. Quality of Reporting of Meta-analyses. Lancet 354: 1896-1900.

11) Jiamton S, Pepin J, Suttent R, Filteau S, Mahakkanukrauh B, Hanshaoworakul W, Chaisilwattana P, Suthipinittharm P, Shetty P, Jaffar S. 2003. A randomized trial of the impact of multiple micronutrient supplementation on mortality among HIV-infected individuals living in Bangkok. AIDS 17: 2461-2469.

12) Fawzi WW, Msamanga GI, Spiegelman D, Wei R, Kapiga S, Villamor E, Mwakagile D, Mugusi F, Hertzmark E, Essex M, Hunter DJ. 2004. A randomized trial of multivitamin supplements and HIV disease progression and mortality. N Engl J Med 351: 23-32.

13) Range N, Changalucha J, Krarup H, Magnussen $P$, Andersen AB, Friis H. 2006. The effect of multi-vita$\mathrm{min} /$ mineral supplementation on mortality during treatment of pulmonary tuberculosis: a randomised two-by-two factorial trial in Mwanza, Tanzania. Br J Nutr 95: 762-770.

14) Semba RD, Kumwenda J, Zijlstra E, Ricks MO, van Lettow M, Whalen C, Clark TD, Jorgensen L, Kohler J, Kumwenda N, Taha TE, Harries AD. 2007. Micronutrient supplements and mortality of HIV-infected adults with pulmonary TB: a controlled clinical trial. Int J Tuberc Lung Dis 11: 854-859.

15) Kelly P, Katubulushi M, Todd J, Banda R, Yambayamba V, Fwoloshi M, Zulu I, Kafwembe E, Yavwa F, Sanderson IR, Tomkins A. 2008. Micronutrient supplementation has limited effects on intestinal infectious disease and mortality in a Zambian population of mixed HIV status: a cluster randomized trial. Am J Clin Nutr 88: 10101017.

16) Villamor E, Mugusi F, Urassa W, Bosch RJ, Saathoff E, Matsumoto K, Meydani SN, Fawzi WW. 2008. A trial of the effect of micronutrient supplementation on treatment outcome, T cell counts, morbidity, and mortality in adults with pulmonary tuberculosis. J Infect Dis 197: 1499-1505. 
17) Do H. 2000. Dietary Reference Values: A Guide. HMSO, London.

18) Niki E, Kawakami A, Saito M, Yamamoto Y, Tsuchiya J, Kamiya Y. 1985. Effect of phytyl side chain of vitamin E on its antioxidant activity. J Biol Chem 260: 21912196.

19) Beyer RE. 1994. The role of ascorbate in antioxidant protection of biomembranes: interaction with vitamin $\mathrm{E}$ and coenzyme Q. J Bioenerg Biomembr 26: 349-358.

20) Maruya M, Suzuki K, Fujimoto H, Miyajima M, Kanagawa O, Wakayama T, Fagarasan S. 2011. Vitamin Adependent transcriptional activation of the nuclear factor of activated T cells c1 (NFATc1) is critical for the development and survival of B1 cells. Proc Natl Acad Sci USA 108: 722-727.

21) Lukasova M, Malaval C, Gille A, Kero J, Offermanns S. 2011. Nicotinic acid inhibits progression of atherosclerosis in mice through its receptor GPR109A expressed by immune cells. J Clin Invest 121: 1163-1173.

22) Lonn E, Bosch J, Yusuf S, Sheridan P, Pogue J, Arnold JM, Ross C, Arnold A, Sleight P, Probstfield J, Dagenais GR. 2005. Effects of long-term vitamin E supplementation on cardiovascular events and cancer: a randomized controlled trial. JAMA 293: 1338-1347.

23) High KP. 1999. Micronutrient supplementation and immune function in the elderly. Clin Infect Dis 28: 717722.

24) de Azevedo Paiva A, Rondo PH, Rehder Vaz-de-Lima L, de Freitas Oliveira C, Ueda M, Goncalves-Carvalho C, Reinaldo LG. 2010. The impact of vitamin A supplementation on the immune system of vitamin A-deficient children. Int J Vitam Nutr Res 80: 188-196.

25) Papadopulos-Eleopulos E, Turner VF, Papadimitriou JM. 1992. Oxidative stress, HIV and AIDS. Res Immunol 143: 145-148.

26) Baruchel S, Wainberg MA. 1992. The role of oxidative stress in disease progression in individuals infected by the human immunodeficiency virus. J Leukoc Biol 52: 111-114.

27) Allard JP, Aghdassi E, Chau J, Salit I, Walmsley S. 1998. Oxidative stress and plasma antioxidant micronutrients in humans with HIV infection. Am J Clin Nutr 67: 143147.

28) Wheeler DA, Gibert CL, Launer CA, Muurahainen N, Elion RA, Abrams DI, Bartsch GE. 1998. Weight loss as a predictor of survival and disease progression in HIV infection. Terry Beirn Community Programs for Clinical Research on AIDS. J Acquir Immune Defic Syndr Hum Retrovirol 18: 80-85.

29) Ott M, Fischer H, Polat H, Helm EB, Frenz M, Caspary WF, Lembcke B. 1995. Bioelectrical impedance analysis as a predictor of survival in patients with human immunodeficiency virus infection. J Acquir Immune Defic Syndr Hum Retrovirol 9: 20-25.

30) van der Sande MA, Schim van der Loeff MF, Aveika AA, Sabally S, Togun T, Sarge-Njie R, Alabi AS, Jaye A, Corrah T, Whittle HC. 2004. Body mass index at time of HIV diagnosis: a strong and independent predictor of survival. J Acquir Immune Defic Syndr 37: 1288-1294.
31) Lorenz KA, Shapiro MF, Asch SM, Bozzette SA, Hays RD. 2001. Associations of symptoms and health-related quality of life: findings from a national study of persons with HIV infection. Ann Intern Med 134: 854-860.

32) Cunningham-Rundles S. 2001. Nutrition and the mucosal immune system. Curr Opin Gastroenterol 17: 171-176.

33) Nair PP, Lohani A, Norkus EP, Feagins H, Bhagavan HN. 1996. Uptake and distribution of carotenoids, retinol, and tocopherols in human colonic epithelial cells in vivo. Cancer Epidemiol Biomarkers Prev 5: 913-916.

34) Fournier AM, Dickinson GM, Erdfrocht IR, Cleary T, Fischl MA. 1988. Tuberculosis and nontuberculous mycobacteriosis in patients with AIDS. Chest 93: 772-775.

35) Riedel W, Maulik G. 1999. Fever: an integrated response of the central nervous system to oxidative stress. Mol Cell Biochem 196: 125-132.

36) Zinchuk V. 1999. Effect of nitric oxide synthase inhibition on hemoglobin-oxygen affinity and lipid peroxidation in rabbits during fever. Respiration 66: 448-454.

37) Brzezinska-Slebodzinska E. 2001. Fever induced oxidative stress: the effect on thyroid status and the 5'-monodeiodinase activity, protective role of selenium and vitamin E. J Physiol Pharmacol 52: 275-284.

38) Maennle DL, Grierson HL, Gnarra DG, Weisenburger DD. 1991. Sinus histiocytosis with massive lymphadenopathy: a spectrum of disease associated with immune dysfunction. Pediatr Pathol 11: 399-412.

39) Packer JE, Slater TF, Willson RL. 1979. Direct observation of a free radical interaction between vitamin $\mathrm{E}$ and vitamin C. Nature 278: 737-738.

40) Ganther HE. 1980. Interactions of vitamin E and selenium with mercury and silver. Ann NY Acad Sci 355: 212-226.

41) Niki E, Noguchi N, Tsuchihashi H, Gotoh N. 1995. Interaction among vitamin $\mathrm{C}$, vitamin $\mathrm{E}$, and beta-carotene. Am J Clin Nutr 62: 1322S-1326S.

42) Bettger WJ, Fish TJ, O'Dell B L. 1978. Effects of copper and zinc status of rats on erythrocyte stability and superoxide dismutase activity. Proc Soc Exp Biol Med 158: 279-282.

43) Wejse C, Gomes VF, Rabna P, Gustafson P, Aaby P, Lisse IM, Andersen PL, Glerup H, Sodemann M. 2009. Vitamin D as supplementary treatment for tuberculosis: a double-blind, randomized, placebo-controlled trial. Am J Respir Crit Care Med 179: 843-850.

44) Kupka R, Mugusi F, Aboud S, Hertzmark E, Spiegelman D, Fawzi WW. 2009. Effect of selenium supplements on hemoglobin concentration and morbidity among HIV1-infected Tanzanian women. Clin Infect Dis 48: 14751478.

45) Winkler P, Ellinger S, Boetzer AM, Arendt BM, Berthold HK, Rockstroh JK, Spengler U, Goerlich R. 2004. Lymphocyte proliferation and apoptosis in HIV-seropositive and healthy subjects during long-term ingestion of fruit juices or a fruit-vegetable-concentrate rich in polyphenols and antioxidant vitamins. Eur J Clin Nutr 58: 317325. 